\title{
The Liver and Postheparin Plasma Lipolytic Activity in Dog and Man*
}

\author{
Robert E. Condon, $\dagger$ Hillel Tobias, $\$$ and Dharam V. Datta $\S$ \\ (From the Medical Unit, Royal Free Hospital, London, England)
}

The intravascular injection of heparin results in the rapid appearance in the blood of a lipolytic enzyme capable of clearing lipemic sera and hydrolyzing artificial triglyceride emulsions $(1,2)$. This enzyme has been termed clearing factor (3), lipoprotein lipase (4), clearing factor lipase (2), or postheparin plasma lipolytic activity (PHLA) (5). A lipolytic enzyme with characteristics nearly identical to those of PHLA has been identified in relatively high concentration in tissue extracts of heart (4), adipose tissue (6), and mammary gland $(7,8)$. Lower concentrations of this lipolytic enzyme have been found in tissue extracts of thoracic and abdominal viscera, including the liver $(3,4,9)$.

Release of PHLA from tissue sources into the circulation has been demonstrated in perfusion studies of limbs and abdominothoracic viscera (3, $10,11)$. However, perfusion of the isolated rat liver with heparinized blood has been reported by several observers $(10,12-14)$ to result in net loss of PHLA and no release of lipolytic activity by the liver. Boberg, Carlson, and Normell (15), on the other hand, have reported recently in an abstract that the isolated perfused canine liver

\footnotetext{
* Submitted for publication August 24, 1964; accepted January 28, 1965.

Supported in part by grants from the Prudential Life Assurance Company, London, and the National Institutes of Health, Bethesda, Md. (GM-325 and 4F2 AM-19, 701-02).

Preliminary reports of portions of this work have been presented to the Medical Research Society, London, April 1964, and to the Surgical Forum, American College of Surgeons, Chicago, October 1964.

† Guggenheim Fellow. Present address: Department of Surgery, University of Washington, Seattle 5, Wash.

$\ddagger$ Postdoctoral Fellow, National Institute of Arthritis and Metabolic Diseases. Address requests for reprints to Dr. Hillel Tobias, Medical Unit, Royal Free Hospital, Gray's Inn Road, London, W.C. 1, England.

§ Present address: Gastroenterology Unit, Massachusetts General Hospital, Boston 14, Mass.
}

is capable of producing lipolytic activity in response to heparin. LeQuire, Hamilton, Adams, and Merrill (16) also found increases in lipolytic activity of blood drawn from the inferior vena cava after injection of heparin into the portal vein. The relative importance in intact animals of various tissues as sources of PHLA has not been clearly established.

Studies in man have shown a decrease in the efficiency of hepatic removal of lipolytic activity in patients with cirrhosis (17). This has been confirmed in animals subjected either to carbon tetrachloride induced necrosis or to functional hepatectomy (17-19). Thus it would appear that the maximal levels of PHLA should be higher or the same in cirrhotic patients as compared with normal controls. However, when PHLA was determined by improved assay techniques, significantly lower levels of lipolytic activity were found in cirrhotic patients than in normal subjects (1921).

A possible explanation for the finding of lower levels of PHLA in cirrhotic patients lies in the hypothesis that the liver serves as an important source of PHLA in the normal individual, and this source is compromised in patients with cirrhosis. In this investigation of the effect of heparin injection on hepatic venous PHLA in intact dogs and man, we have shown that the liver can release PHLA in animals and man and that the liver may be an important source of this enzyme.

\section{Methods}

Four groups of healthy mongrel dogs were used (Table I). Heparin was injected into the portal vein in animals with an intact liver (protocol A) and at a comparable site after total hepatectomy (protocol B). The effect of heparin injected into the peripheral circulation was studied in animals with an intact liver (protocols $\mathrm{C}$ and $\mathrm{D}$ ), and also in an animal after hepatectomy (protocol $\mathrm{E}$ ). 
Two patients were studied during the course of clinically indicated hepatic vein catheterizations.

Patient A.B. was a 52-year-old white man, who had histologically confirmed postnecrotic cirrhosis and who appeared very fit on clinical examination. A hard liver was palpable approximately $5 \mathrm{~cm}$ below the xiphoid in the epigastrium. The spleen was very firm and palpable $6 \mathrm{~cm}$ below the left costal margin. No ascites, hepatic fetor, or asterixis was detected. Esophageal varices were revealed radiographically by barium swallow, and an extensive portosystemic collateral circulation was demonstrated by splenic venogram. The intrasplenic pressure was $25 \mathrm{~mm} \mathrm{Hg}$ and the wedged hepatic vein pressure $35 \mathrm{~mm} \mathrm{Hg}$. Laboratory studies showed a hematocrit of 47, serum total bilirubin $0.7 \mathrm{mg}$ per $100 \mathrm{ml}$, albumin $3.3 \mathrm{~g}$ per $100 \mathrm{ml}$, alkaline phosphatase $11 \mathrm{King}$-Armstrong units per $100 \mathrm{ml}$, aspartate transaminase 21 international units per L, and prothrombin time 13 seconds (control 12 seconds).

Patient R.B. was a 40-year-old white man, who had histologically confirmed postnecrotic cirrhosis. An end to side portacaval shunt, which was functioning at the time of our study, had been constructed 6 years previously. $\mathrm{He}$ appeared chronically ill, was jaundiced, and had a small amount of ascites. Laboratory investigations showed a hematocrit of 31 , serum total bilirubin $7.7 \mathrm{mg}$ per $100 \mathrm{ml}$, albumin $1.6 \mathrm{mg}$ per $100 \mathrm{ml}$, alkaline phosphatase 27 King-Armstrong $U$ per $100 \mathrm{ml}$, aspartate transaminase $47 \mathrm{IU}$ per $\mathrm{L}$, and prothrombin time 18 seconds (control 14 seconds).

Preparation of animals. Dogs maintained on a normal kennel diet and weighing 12 to $28 \mathrm{~kg}$ were fasted for 12 to 15 hours and lightly anesthetized with intravenous pentobarbital. Anesthesia was then maintained with equal volumes of nitrous oxide and oxygen through a cuffed endotracheal tube. All operations were carried out with aseptic precautions through a mid-line thoracoabdominal incision. Catheters were placed into the main left hepatic vein via the right jugular vein, into the portal vein via a distal ileal vein, and into the vena cava and abdominal aorta below the renal vessels via the right femoral vein and artery. All catheters were kept patent with a slow infusion of $0.9 \%$ (wt/vol) sodium chloride. The location of the tip of each catheter was confirmed by palpation before any blood samples were taken and further confirmed by dissection at the conclusion of the experiment. In those animals subjected to hepatectomy, a preliminary end to side portacaval shunt was constructed and the liver then totally excised.

Injection of heparin. After drawing base-line specimens, sodium heparin, $10 \mathrm{U}(0.1 \mathrm{mg})$ per $\mathrm{kg}$ body weight was injected into the designated blood vessel (Table I). Injections into the femoral artery (protocols $\mathrm{D}$ and $\mathrm{E}$ ) were made through an additional catheter that had been introduced percutaneously (22) into the vessel for a short distance in a distal direction without interfering with blood flow to the limb. During injection of heparin, the femoral artery was temporarily oc-

\footnotetext{
1 Boots Pure Drug Company Ltd., London, England.
}

TABLE I

Outline of animal experiments

\begin{tabular}{cllc}
\hline Protocol & Liver status & $\begin{array}{c}\text { Site of heparin } \\
\text { injection }\end{array}$ & $\begin{array}{c}\text { No. of } \\
\text { animals }\end{array}$ \\
\hline A & Intact & $\begin{array}{c}\text { Portal vein in the } \\
\text { hilum }\end{array}$ & 6 \\
B & Hepatectomized & $\begin{array}{c}\text { Supradiaphragmatic } \\
\text { inferior vena cava } \\
\text { Abdominal aorta be- } \\
\text { low renal vessels }\end{array}$ & 4 \\
C & Intact & $\begin{array}{c}\text { Femoral artery } \\
\text { Femoral artery }\end{array}$ & 4 \\
D & Intact & Hepatectomized & 1 \\
E & & &
\end{tabular}

cluded proximal to the site of injection. The beginning of the heparin injection was taken as zero time, and injection was completed within two seconds in all experiments.

Circulation time. In two animal experiments, human serum albumin labeled with $10 \mu \mathrm{c} \mathrm{I}^{1312}$ in a volume of 1 $\mathrm{ml}$ was mixed with the heparin to be injected. Portions of the aortic blood samples that were drawn subsequently were assayed for radioactivity in a sodium iodide crystal well-type scintillation counter to determine the circulation time to the aorta from the point of injection.

Handling of blood samples. Blood within the catheter "dead space" was aspirated and discarded just before withdrawal of each specimen. Five-ml specimens of blood were withdrawn simultaneously from each of the catheters into siliconized syringes. The samples were immediately transferred to cold plastic tubes containing $15 \mathrm{U}$ of heparin and placed in ice. The blood samples were spun for 15 minutes at $3,000 \mathrm{rpm}$ in a refrigerated centrifuge at $0^{\circ} \mathrm{C}$, and the plasma was separated. Plasma was either assayed immediately or frozen for subsequent estimation of lipolytic activity. Freezing of plasma and storage for periods of up to 68 days does not affect measurement of PHLA (21).

Assay for lipolytic activity. All estimations were done in duplicate by a method described previously using $\mathbf{0 . 2}$ $\mathrm{ml}$ of plasma (20). The lipolytic activity of each specimen was expressed as the mean microequivalents of free fatty acids (FFA) released per hour of incubation per milliliter of plasma. The substrate consisted of $30 \%$ coconut oil emulsion stabilized with $1 \%$ polysorbate 60 and $1.5 \%$ glycerol monostearate. In this system of lipolysis, zero-order enzyme kinetics could be observed for 120 minutes (21).

Characterization of lipolytic activity. The PHLA of hepatic vein blood obtained from an intact dog within 5 seconds of heparin injection into portal vein, and before the appearance of lipolytic activity elsewhere in the vascular tree, was studied with regard to its ability to act on chylomicrons and lipoproteins. Postheparin plasma obtained from the hind limbs of another intact animal on first circulation after femoral artery injection was also studied in this manner.

\footnotetext{
2 The Radiochemical Center, Amersham, England.
} 
Chylomicrons were obtained from a donor dog by thoracic duct cannulation after oral administration of corn oil. Low density lipoproteins were obtained from the donor dog plasma. Chylomicrons and low density lipoproteins were separated according to the method of Korn (23). Free fatty acid release induced by postheparin plasma from the hepatic vein was determined using $5 \mathrm{mg}$ each of chylomicrons and lipoproteins, in separate experiments. Final volume of assay system was $1.5 \mathrm{ml}$. FFA release after 1 hour was measured.

Clearing activity was also studied by measuring changes in optical density of coconut oil emulsion at $570 \mu$ using the method of Korn (23). $4.5 \mathrm{ml}$ of postheparin plasma was incubated with $0.3 \mathrm{ml}$ of $2 \%$ coconut oil emulsion for 1 hour at $37^{\circ}$. The effect of $1.0 \mathrm{M} \mathrm{NaCl}$ on lipolysis and clearing was also determined.

Inhibitor evaluation. The possibility that demonstration of lower PHLA in hepatectomized dogs might be due to accumulation of a plasma inhibitor normally removed by the liver was investigated. Preheparin plasma of a hepatectomized dog was mixed with postheparin plasma of a dog with intact liver, and FFA release was measured. Final volume of the assay system was kept constant using Tris buffer.

Studies in man. The patients were fasted for 12 to 14 hours and received $200 \mathrm{mg}$ secobarbital 2 hours before study. A right hepatic vein was catheterized with a no. 9 Cournand catheter introduced via the basilic vein under fluoroscopic control and patency maintained by a slow infusion of $0.9 \%$ (wt/vol) sodium chloride. Arterial blood was obtained from an indwelling polyethylene catheter introduced percutaneously via the femoral artery (22). Heparin was injected into the femoral vein in one patient (A.B.) and into the aorta above the celiac axis in the other patient (R.B.). Dosage of heparin and handling and assay of blood samples were identical with the techniques employed in the animal experiments.

The differences between means were analyzed by $t$ test using paired comparisons when applicable (24).

TABLE II

Postheparin plasma lipolytic activity (PHLA) (mean microequivalents FFA per hour per milliliter plasma) after portal vein heparin injection in intact dogs (protocol $A$ )

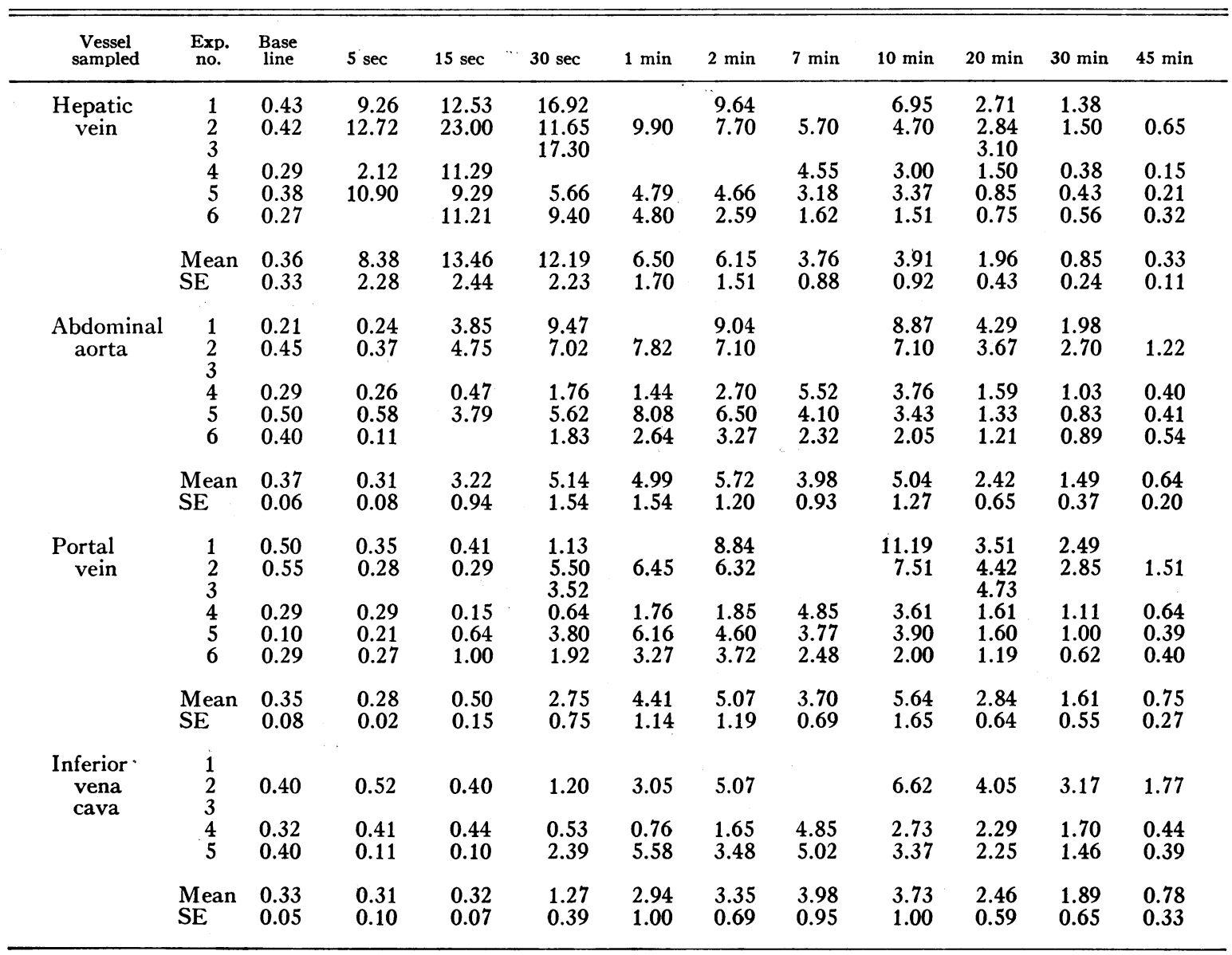


TABLE III

PHLA (mean microequivalents FFA per hour per milliliter plasma) in hepatectomized dogs (protocol B)

\begin{tabular}{|c|c|c|c|c|c|c|c|c|c|c|c|}
\hline $\begin{array}{c}\text { Vessel } \\
\text { sampled }\end{array}$ & $\begin{array}{c}\text { Exp. } \\
\text { no. }\end{array}$ & $\begin{array}{l}\text { Base } \\
\text { line }\end{array}$ & $5 \mathrm{sec}$ & $15 \mathrm{sec}$ & $30 \mathrm{sec}$ & $1 \mathrm{~min}$ & $10 \mathrm{~min}$ & $20 \mathrm{~min}$ & $30 \mathrm{~min}$ & $45 \mathrm{~min}$ & $60 \mathrm{~min}$ \\
\hline \multirow[t]{2}{*}{$\begin{array}{l}\text { Abdominal } \\
\text { aorta }\end{array}$} & $\begin{array}{l}1 \\
2 \\
3 \\
4\end{array}$ & $\begin{array}{l}0.20 \\
0.30 \\
0.00 \\
0.10\end{array}$ & $\begin{array}{l}0.13 \\
0.51 \\
0.28 \\
0.10\end{array}$ & $\begin{array}{l}0.34 \\
0.63 \\
0.26 \\
0.36\end{array}$ & $\begin{array}{l}0.10 \\
0.46 \\
0.30 \\
0.24\end{array}$ & $\begin{array}{l}0.45 \\
1.32 \\
0.30 \\
1.37\end{array}$ & $\begin{array}{l}0.89 \\
4.00 \\
1.31 \\
2.74\end{array}$ & $\begin{array}{l}1.00 \\
3.10 \\
1.40 \\
3.13\end{array}$ & $\begin{array}{l}0.73 \\
\\
1.40 \\
2.44\end{array}$ & $\begin{array}{l}1.10 \\
2.83 \\
1.16 \\
1.65\end{array}$ & $\begin{array}{l}2.00 \\
1.12 \\
1.46\end{array}$ \\
\hline & $\begin{array}{l}\text { Mean } \\
\text { SE }\end{array}$ & $\begin{array}{l}0.15 \\
0.07\end{array}$ & $\begin{array}{l}0.26 \\
0.11\end{array}$ & $\begin{array}{l}0.40 \\
0.08\end{array}$ & $\begin{array}{l}0.28 \\
0.07\end{array}$ & $\begin{array}{l}0.86 \\
0.28\end{array}$ & $\begin{array}{l}2.24 \\
0.71\end{array}$ & $\begin{array}{l}2.16 \\
0.55\end{array}$ & $\begin{array}{l}1.14 \\
0.50\end{array}$ & $\begin{array}{l}1.69 \\
0.40\end{array}$ & $\begin{array}{l}1.15 \\
0.26\end{array}$ \\
\hline \multirow[t]{2}{*}{$\begin{array}{r}\text { Portal } \\
\text { vein }\end{array}$} & $\begin{array}{l}1 \\
2 \\
3 \\
4\end{array}$ & $\begin{array}{l}0.57 \\
0.21 \\
0.33 \\
0.13\end{array}$ & $\begin{array}{l}0.52 \\
0.14 \\
0.28 \\
0.00\end{array}$ & $\begin{array}{l}0.26 \\
0.90 \\
0.14 \\
0.26\end{array}$ & $\begin{array}{l}1.00 \\
1.39 \\
0.19 \\
0.24\end{array}$ & $\begin{array}{l}0.47 \\
1.79 \\
0.71 \\
0.52\end{array}$ & $\begin{array}{l}1.79 \\
3.95 \\
1.31 \\
2.86\end{array}$ & $\begin{array}{l}1.05 \\
3.30 \\
1.40 \\
2.72\end{array}$ & $\begin{array}{l}0.81 \\
2.16 \\
1.40 \\
2.30\end{array}$ & $\begin{array}{l}1.08 \\
2.93 \\
1.36 \\
1.46\end{array}$ & $\begin{array}{l}2.60 \\
1.37 \\
1.23\end{array}$ \\
\hline & $\begin{array}{l}\text { Mean } \\
\text { SE }\end{array}$ & $\begin{array}{l}0.31 \\
0.10\end{array}$ & $\begin{array}{l}0.24 \\
0.11\end{array}$ & $\begin{array}{l}0.39 \\
0.17\end{array}$ & $\begin{array}{l}0.71 \\
0.36\end{array}$ & $\begin{array}{l}0.87 \\
0.31\end{array}$ & $\begin{array}{l}2.48 \\
0.59\end{array}$ & $\begin{array}{l}2.12 \\
0.53\end{array}$ & $\begin{array}{l}1.67 \\
0.35\end{array}$ & $\begin{array}{l}1.71 \\
0.42\end{array}$ & $\begin{array}{l}1.30 \\
0.43\end{array}$ \\
\hline \multirow[t]{2}{*}{$\begin{array}{c}\text { Inferior } \\
\text { vena } \\
\text { cava }\end{array}$} & $\begin{array}{l}1 \\
2 \\
3 \\
4\end{array}$ & $\begin{array}{l}0.05 \\
0.21 \\
0.35 \\
0.36\end{array}$ & $\begin{array}{l}0.18 \\
0.14 \\
0.26 \\
0.41\end{array}$ & $\begin{array}{l}0.05 \\
0.10 \\
0.09 \\
0.24\end{array}$ & $\begin{array}{l}0.23 \\
0.32 \\
0.12 \\
0.26\end{array}$ & $\begin{array}{l}0.60 \\
1.18 \\
0.12 \\
2.95\end{array}$ & $\begin{array}{l}0.97 \\
3.95 \\
1.50 \\
2.84\end{array}$ & $\begin{array}{l}0.71 \\
2.62 \\
0.56 \\
3.00\end{array}$ & $\begin{array}{l}0.92 \\
2.16 \\
1.40 \\
2.30\end{array}$ & $\begin{array}{l}0.71 \\
2.69 \\
1.33 \\
2.09\end{array}$ & $\begin{array}{l}2.09 \\
1.09 \\
1.68\end{array}$ \\
\hline & $\begin{array}{l}\text { Mean } \\
\text { SE }\end{array}$ & $\begin{array}{l}0.24 \\
0.07\end{array}$ & $\begin{array}{l}0.25 \\
0.05\end{array}$ & $\begin{array}{l}0.12 \\
0.04\end{array}$ & $\begin{array}{l}0.23 \\
0.05\end{array}$ & $\begin{array}{l}1.21 \\
0.63\end{array}$ & $\begin{array}{l}2.32 \\
0.63\end{array}$ & $\begin{array}{l}1.72 \\
0.55\end{array}$ & $\begin{array}{l}1.70 \\
0.35\end{array}$ & $\begin{array}{l}1.71 \\
0.43\end{array}$ & $\begin{array}{l}1.22 \\
0.24\end{array}$ \\
\hline
\end{tabular}

\section{Results}

Injection of heparin into the portal vein of dogs with an intact liver (protocol A) resulted in an increase in lipolytic activity of the blood leaving the liver (Table II). Five seconds after injection, PHLA in hepatic vein had increased significantly above its base-line value $(p<0.05)$. The hepatic vein PHLA remained significantly elevated $(p<0.05)$ above the PHLA of aorta, portal vein, and inferior vena cava throughout the initial 15 seconds after heparin injection. Hepatic vein PHLA continued to be significantly higher $(p<0.05)$ than that of portal vein or inferior vena cava for at least 30 seconds after injection into portal vein.

The appearance of PHLA in aorta lagged 15 to 30 seconds behind hepatic vein in all of these experiments. The time of appearance in two dogs (no. 4 and 5) of lipolytic activity in aorta coincided with the time taken for radioactive albumin simultaneously injected into portal vein to circulate to abdominal aorta. At this time there was still no increase in lipolytic activity of blood from either the portal vein or the inferior vena cava $(p<0.05)$. PHLA in both the portal vein and inferior vena cava did not begin to rise until 30 seconds after heparin injection.
The second group of animals (protocol B) underwent total surgical hepatectomy (Table III). Heparin was injected into the supradiaphragmatic inferior vena cava just above the level of the ligated hepatic veins. This injection site was selected to provide conditions comparable with portal vein injection in the intact animals. The mean maximal arterial levels of PHLA were significantly lower in the hepatectomized animals than in animals with intact livers $(p<0.05)$. Rapid release of the enzyme, as had been found in the dogs with an intact liver, was not seen in these experiments (Figure 1).

Preheparin plasma of a hepatectomized dog failed to inhibit lipolytic activity when incubated with postheparin plasma of a dog with intact liver. Thus the lower lipolytic activity seen after hepatectomy was not due to the presence of inhibitor substances in plasma (Table IV).

The effects of heparin injection into the peripheral arterial circulation were followed in a third group of animals (protocols $\mathrm{C}$ and $\mathrm{D}$ ). In an initial experiment (Table V) heparin injected into the aorta below the renal arteries resulted in rapid release of lipolytic activity from the liver. In subsequent experiments in this group, in order to avoid the possibility of heparin reaching the 


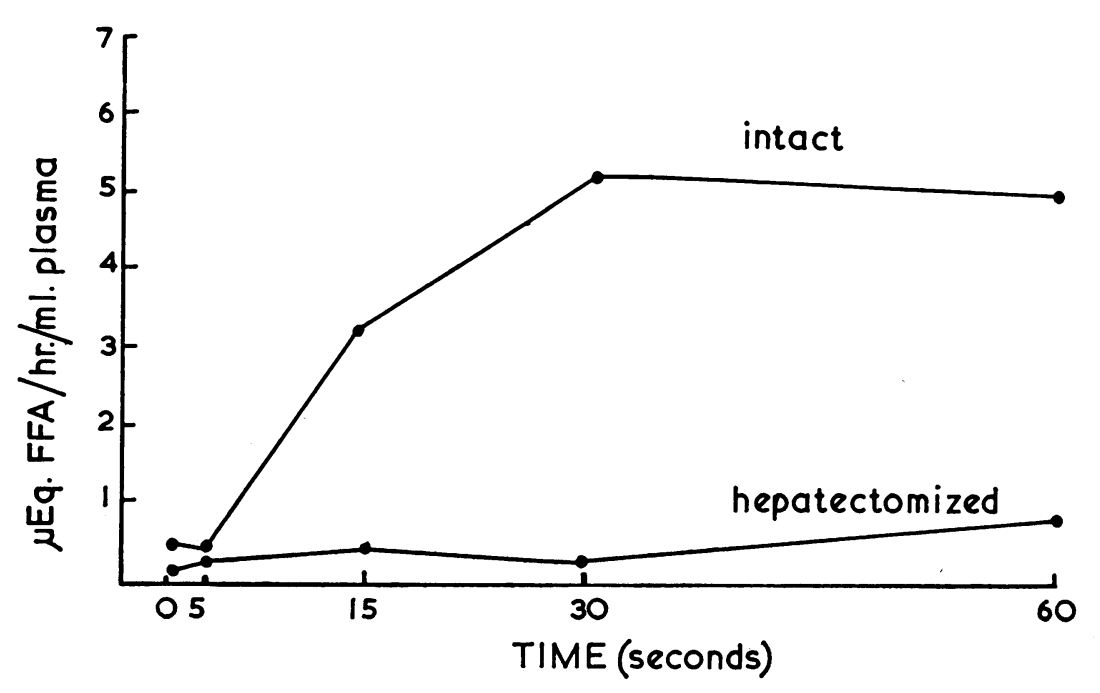

Fig. 1. Mean arterial postheparin plasma lipolytic activity (PHLA) LEVELS IN INTACT AND HEPATECTOMIZED DOGS.

liver directly by reflux via hepatic artery, heparin was injected into the left femoral artery below the groin while the artery proximal to the site of injection was momentarily occluded (Table VI). Under these conditions of administration heparin would initially circulate through the hind limb, allowing opportunity for the release of PHLA from the limb, before reaching the liver via the hepatic artery and portal vein.

Injection of heparin into the femoral artery resulted in the release of small amounts of PHLA from the hind limb, as indicated by an initial positive difference between the mean lipolytic activity in inferior vena cava as compared with aorta $(p<0.05)$. During the initial 15 seconds there was no change in the lipolytic activity in hepatic vein. However, beginning 30 seconds

TABLE IV

Inhibitor studies; effect of preheparin plasma of a hepatectomized dog on lipolytic activity of postheparin plasma of a dog with intact liver

\begin{tabular}{ccc}
\hline \hline $\begin{array}{c}\text { Preheparin } \\
\text { plasma of } \\
\text { hepatectomized } \\
\text { dog }\end{array}$ & $\begin{array}{c}\text { Postheparin } \\
\text { plasma of } \\
\text { dog with } \\
\text { intact liver }\end{array}$ & $\begin{array}{c}\text { FFA released } \\
\text { per hour }\end{array}$ \\
\hline$m l$ & $m l$ & $\mu E q$ \\
& 0.1 & 0.78 \\
& 0.2 & 1.53 \\
0.1 & & 0.12 \\
0.2 & 0.1 & 0.22 \\
0.1 & 0.1 & 0.89 \\
0.2 & 0.1 & 1.02 \\
\hline
\end{tabular}

after heparin injection into the femoral artery and presumably after heparin had circulated to the liver, the level of lipolytic activity in the hepatic vein rose above that of the vena cava (Figure 2). Two minutes after injection of heparin, the mean level of hepatic vein PHLA was significantly greater than that of vena cava $(p<0.05)$. This apparent release of PHLA from the liver was associated with a reversal of the gradient of lipolytic activity between vena cava and aorta. The level of activity in the artery remained above that of the vena cava during the period from 1 to 7 minutes after heparin injection.

The effect of heparin injection into the femoral artery also was investigated in one animal who had had a hepatectomy (Table VII). Ten minutes after injection of heparin in the hepatectomized animal, the levels of PHLA in both aorta and vena cava were below the $95 \%$ confidence limits of the mean of the peripherally injected intact animals, indicating a significantly lower release of PHLA into the circulation in the absence of the liver. In addition, the lipolytic activity in the vena cava remained above that of the aorta throughout the first 10 minutes after heparin injection, implying that the hind limb tissues were the chief source of the small amounts of PHLA released into the circulation under these conditions.

With regard to hepatic removal of PHLA, 
TABLE V

PHLA (mean microequivalents FFA per hour per milliliter plasma) after heparin injection into aorta in intact dog (protocol $C$ )

\begin{tabular}{|c|c|c|c|c|c|c|c|c|c|c|c|c|}
\hline $\begin{array}{c}\text { Vessel } \\
\text { sampled }\end{array}$ & $\begin{array}{l}\text { Base } \\
\text { line }\end{array}$ & $5 \mathrm{sec}$ & $15 \mathrm{sec}$ & $30 \mathrm{sec}$ & $1 \mathrm{~min}$ & $2 \mathrm{~min}$ & $7 \mathrm{~min}$ & $10 \mathrm{~min}$ & $20 \mathrm{~min}$ & $30 \mathrm{~min}$ & $45 \mathrm{~min}$ & $60 \mathrm{~min}$ \\
\hline $\begin{array}{l}\text { Hepatic } \\
\text { vein }\end{array}$ & 0.10 & 0.23 & 3.54 & 10.90 & 12.97 & 9.77 & 4.91 & 3.74 & 2.08 & 1.31 & 0.15 & 0.10 \\
\hline $\begin{array}{l}\text { Abdominal } \\
\text { aorta }\end{array}$ & 0.10 & 0.29 & 0.43 & 2.45 & 6.60 & 6.14 & 4.61 & 3.91 & 2.51 & 2.11 & 0.86 & 0.40 \\
\hline $\begin{array}{r}\text { Portal } \\
\text { vein }\end{array}$ & 0.25 & 1.00 & 1.03 & 1.65 & 6.14 & 5.48 & 4.34 & 5.08 & 2.48 & 1.72 & 0.60 & 0.29 \\
\hline $\begin{array}{c}\text { Inferior } \\
\text { vena } \\
\text { cava }\end{array}$ & 0.22 & 0.54 & 0.86 & 0.86 & 1.94 & 3.65 & 6.17 & 5.42 & 3.05 & 2.28 & 0.48 & 0.20 \\
\hline
\end{tabular}

there is a negative PHLA gradient across the liver during the period from 20 to 45 minutes after heparin injection in all intact animals studied (protocols A, C, and D; Tables II, V, and VI). The pooled arterial-hepatic vein and portal veinhepatic vein mean activity differences of the in- tact dogs are significant throughout this period $(\mathrm{p}<0.05)$.

Hepatic vein plasma, obtained in the first circulation after heparin injection into the portal vein, and inferior vena cava plasma, obtained in the first circulation after heparin injection into the femoral

TABLE VI

PHLA (mean microequivalents FFA per hour per milliliter plasma) after femoral artery injection of heparin in intact dogs (protocol D)

\begin{tabular}{|c|c|c|c|c|c|c|c|c|c|c|c|c|}
\hline $\begin{array}{l}\text { Vessel } \\
\text { sampled }\end{array}$ & $\begin{array}{c}\text { Exp. } \\
\text { no. }\end{array}$ & $\begin{array}{c}\text { Base } \\
\text { line }\end{array}$ & $5 \mathrm{sec}$ & $15 \mathrm{sec}$ & $30 \mathrm{sec}$ & $1 \mathrm{~min}$ & $2 \mathrm{~min}$ & $7 \mathrm{~min}$ & $10 \mathrm{~min}$ & $20 \mathrm{~min}$ & $30 \mathrm{~min}$ & $45 \mathrm{~min}$ \\
\hline \multirow[t]{2}{*}{$\begin{array}{l}\text { Hepatic } \\
\text { vein }\end{array}$} & $\begin{array}{l}1 \\
2 \\
3 \\
4\end{array}$ & $\begin{array}{l}0.30 \\
0.00 \\
0.14 \\
0.57\end{array}$ & $\begin{array}{l}0.27 \\
0.00\end{array}$ & $\begin{array}{l}0.24 \\
0.00 \\
0.29\end{array}$ & $\begin{array}{l}0.86 \\
5.37 \\
1.22 \\
0.64\end{array}$ & $\begin{array}{c}0.67 \\
11.43^{*} \\
7.93 \\
9.71\end{array}$ & $\begin{array}{r}8.49 \\
11.58 \\
5.07 \\
8.22\end{array}$ & $\begin{array}{l}7.70 \\
6.00 \\
3.36 \\
6.29\end{array}$ & $\begin{array}{l}5.75 \\
5.07 \\
3.36 \\
4.50\end{array}$ & \multirow[t]{2}{*}{1.49} & \multirow[t]{2}{*}{0.54} & \multirow[t]{2}{*}{0.40} \\
\hline & $\begin{array}{l}\text { Mean } \\
\text { SE }\end{array}$ & $\begin{array}{l}0.25 \\
0.12\end{array}$ & & $\begin{array}{l}0.18 \\
0.11\end{array}$ & $\begin{array}{l}2.02 \\
1.12\end{array}$ & $\begin{array}{l}6.10 \\
2.76\end{array}$ & $\begin{array}{l}8.34 \\
1.33\end{array}$ & $\begin{array}{l}5.84 \\
0.90\end{array}$ & $\begin{array}{l}4.67 \\
0.40\end{array}$ & & & \\
\hline \multirow[t]{2}{*}{$\begin{array}{l}\text { Abdominal } \\
\text { aorta }\end{array}$} & $\begin{array}{l}1 \\
2 \\
3 \\
4\end{array}$ & $\begin{array}{l}0.15 \\
0.00 \\
0.36 \\
0.29\end{array}$ & 0.10 & $\begin{array}{l}0.10 \\
0.00 \\
0.00 \\
0.36\end{array}$ & $\begin{array}{l}0.10 \\
4.00 \\
0.43 \\
0.00\end{array}$ & $\begin{array}{l}0.62 \\
8.43 \\
1.79 \\
2.86\end{array}$ & $\begin{array}{l}1.78 \\
7.22 \\
3.65 \\
5.37\end{array}$ & $\begin{array}{l}9.70 \\
8.86 \\
5.50 \\
5.72\end{array}$ & $\begin{array}{l}7.21 \\
5.37 \\
3.08 \\
8.00\end{array}$ & \multirow[t]{2}{*}{2.71} & \multirow[t]{2}{*}{1.49} & \multirow[t]{2}{*}{5.94} \\
\hline & $\begin{array}{l}\text { Mean } \\
\text { SE }\end{array}$ & $\begin{array}{l}0.20 \\
0.07\end{array}$ & & $\begin{array}{l}0.12 \\
0.08\end{array}$ & $\begin{array}{l}1.13 \\
0.96\end{array}$ & $\begin{array}{l}3.43 \\
1.72\end{array}$ & $\begin{array}{l}4.51 \\
1.17\end{array}$ & $\begin{array}{l}7.45 \\
1.08\end{array}$ & $\begin{array}{l}5.92 \\
1.09\end{array}$ & & & \\
\hline \multirow[t]{2}{*}{$\begin{array}{r}\text { Portal } \\
\text { vein }\end{array}$} & $\begin{array}{l}1 \\
2 \\
3 \\
4\end{array}$ & $\begin{array}{l}0.10 \\
0.00 \\
0.14 \\
0.00\end{array}$ & 0.10 & $\begin{array}{l}0.64 \\
0.71 \\
0.00 \\
0.00\end{array}$ & $\begin{array}{l}0.27 \\
0.36 \\
0.43 \\
0.14\end{array}$ & $\begin{array}{l}1.00 \\
4.57 \\
0.57 \\
0.14\end{array}$ & $\begin{array}{l}2.27 \\
6.29 \\
3.79 \\
3.00\end{array}$ & $\begin{array}{l}8.05 \\
5.93 \\
6.43 \\
5.93\end{array}$ & $\begin{array}{l}3.48 \\
6.08 \\
4.07 \\
7.15\end{array}$ & \multirow[t]{2}{*}{3.64} & \multirow[t]{2}{*}{2.21} & \multirow[t]{2}{*}{0.67} \\
\hline & $\begin{array}{l}\text { Mean } \\
\text { SE }\end{array}$ & $\begin{array}{l}0.06 \\
0.05\end{array}$ & & $\begin{array}{l}0.34 \\
0.19\end{array}$ & $\begin{array}{l}0.30 \\
0.07\end{array}$ & $\begin{array}{l}1.57 \\
1.01\end{array}$ & $\begin{array}{l}3.84 \\
0.87\end{array}$ & $\begin{array}{l}6.59 \\
0.49\end{array}$ & $\begin{array}{l}5.19 \\
0.86\end{array}$ & & & \\
\hline \multirow[t]{2}{*}{$\begin{array}{c}\text { Inferior } \\
\text { vena } \\
\text { cava }\end{array}$} & $\begin{array}{l}1 \\
2 \\
3 \\
4\end{array}$ & $\begin{array}{l}0.10 \\
0.00 \\
0.00 \\
0.86\end{array}$ & 0.72 & $\begin{array}{l}0.81 \\
0.71 \\
1.22 \\
2.64\end{array}$ & $\begin{array}{l}1.13 \\
0.36 \\
1.22 \\
4.57\end{array}$ & $\begin{array}{l}0.86 \\
4.57 \\
1.22 \\
3.94\end{array}$ & $\begin{array}{l}2.18 \\
6.29 \\
2.07 \\
3.50\end{array}$ & $\begin{array}{l}7.70 \\
5.93 \\
5.65 \\
3.72\end{array}$ & $\begin{array}{l}8.75 \\
6.08 \\
5.50 \\
9.93\end{array}$ & \multirow[t]{2}{*}{4.13} & 1.91 & \multirow[t]{2}{*}{0.62} \\
\hline & $\begin{array}{l}\text { Mean } \\
\text { SE }\end{array}$ & $\begin{array}{l}0.24 \\
0.20\end{array}$ & & $\begin{array}{l}1.35 \\
0.45\end{array}$ & $\begin{array}{l}1.82 \\
0.94\end{array}$ & $\begin{array}{l}2.65 \\
0.94\end{array}$ & $\begin{array}{l}3.51 \\
0.98\end{array}$ & $\begin{array}{l}5.75 \\
0.82\end{array}$ & $\begin{array}{l}7.57 \\
1.01\end{array}$ & & & \\
\hline
\end{tabular}

* Sample taken at $1 \frac{1}{2}$ minutes, value not included in mean. 


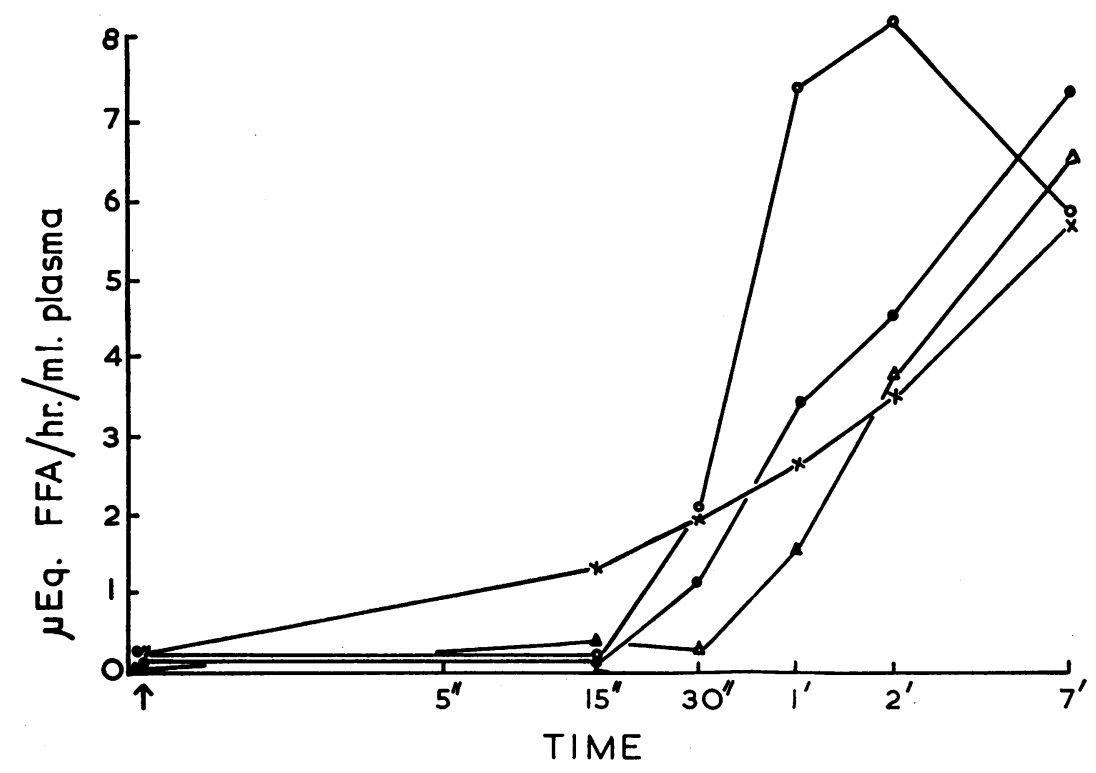

Fig. 2. PHLA LEVELS AFTER PERIPHERAL ARTERIAL INJECTION OF HEPARIN IN INTACT DoGs. Time scale is logarithmic. Symbols: $\bigcirc-O$, hepatic vein; abdominal aorta; $\triangle-\triangle$, portal vein; $X-X$, inferior vena cava.

artery, were capable of effecting the optical clearing of coconut oil emulsion. This clearing was inhibited by $1.0 \mathrm{M}$ sodium chloride (Table VIII). These plasmas were also capable of hydrolyzing chylomicrons and low density lipoproteins. The chylomicron and low density lipoprotein lipolysis was also inhibited by $1.0 \mathrm{M}$ sodium chloride (Table IX).

Both of the patients studied showed increases in hepatic vein PHLA within 15 seconds after heparin injection, whereas simultaneous samples taken from the iliac artery showed little change in PHLA levels. The level of hepatic vein PHLA remained above that of arterial blood for at least 4 minutes after heparin injection (Table $\mathrm{X}$ ).

\section{Discussion}

In our experiments, injection of heparin into the portal vein of intact dogs resulted in release of PHLA into the hepatic vein within 5 seconds. A rise in PHLA in the aorta was not observed until at least 15 seconds after heparin injection into the portal vein and occurred at the same time as the arrival in the aorta of radioactive albumin that had been simultaneously injected with the heparin. The lipolytic activity measured in the aorta at this time represents, in our view, the arrival of the bolus of PHLA that had been released from the liver. It is probable that most of the PHLA measured in the aorta during at

TABLE VII

PHLA (mean microequivalents FFA per hour per milliliter plasma) after femoral artery injection of heparin in a hepatectomized dog (protocol E)

\begin{tabular}{ccccccccccc}
\hline \hline $\begin{array}{c}\text { Vessel } \\
\text { sampled }\end{array}$ & $\begin{array}{c}\text { Base } \\
\text { line }\end{array}$ & $5 \mathrm{sec}$ & $15 \mathrm{sec}$ & $\mathbf{3 0 \mathrm { sec }}$ & $1 \mathrm{~min}$ & $10 \mathrm{~min}$ & $20 \mathrm{~min}$ & $30 \mathrm{~min}$ & $45 \mathrm{~min}$ & $60 \mathrm{~min}$ \\
\hline $\begin{array}{c}\text { Abdominal } \\
\text { aorta }\end{array}$ & 0.10 & 0.10 & 0.10 & 0.39 & 0.27 & 0.54 & 0.54 & 0.58 & 0.77 & 0.20 \\
$\begin{array}{c}\text { Portal } \\
\text { vein }\end{array}$ & 0.20 & 0.10 & 0.10 & 0.20 & 1.00 & 1.48 & 0.71 & 0.25 & 0.35 & 0.74 \\
$\begin{array}{c}\text { Inferior } \\
\text { vena } \\
\text { cava }\end{array}$ & 0.10 & 0.80 & 0.64 & 0.54 & 0.18 & 0.58 & 0.54 & 0.60 & 0.54 & 0.87 \\
\hline
\end{tabular}


TABLE VIII

Optical clearing activity of lipase obtained from liver and hind limb

\begin{tabular}{ccc}
\hline \hline & \multicolumn{2}{c}{$\begin{array}{c}\text { Change in optical density } \\
\text { per hour of incubation }\end{array}$} \\
\cline { 2 - 3 } & & $\begin{array}{c}\text { Plasma } \\
\text { plus }\end{array}$ \\
Source of lipase & $\begin{array}{c}\text { Plasma } \\
\text { alone }\end{array}$ & $\begin{array}{c}1.0 \mathrm{M} \\
\mathrm{NaCl}\end{array}$ \\
\hline Hepatic vein & 0.303 & 0.071 \\
Inferior vena cava & 0.294 & 0.053 \\
\hline
\end{tabular}

least the first minute after portal vein injection of heparin is derived from liver.

The possibility that the release of PHLA from liver after portal vein injection of heparin was merely secondary to a high local concentration of heparin was excluded by injecting heparin into the systemic arterial circulation. It is apparent that even after heparin is injected peripherally, the highest PHLA appears in the hepatic vein rather than in the inferior vena cava, which is draining that portion of the peripheral circulation directly exposed to the injected heparin. The maximal positive mean activity gradient between aorta and vena cava at any time during this group of experiments was less than half that of the maximal positive mean activity gradient between aorta and hepatic vein. It appears that the liver is a relatively efficient site of PHLA release and responds to heparin injection into the systemic circulation.

Hepatectomy results in a marked decrease in lipolytic activity released in response to heparin and provides further evidence in support of our view that liver is a major source of PHLA. If the group of hepatectomized animals in which heparin was injected into the supradiaphragmatic vena cava are compared with the intact animals in which heparin was injected into the portal vein,
TABLE IX

Comparative lipolysis of different substrates (in microequivalents FFA released per hour)

\begin{tabular}{|c|c|c|c|c|}
\hline \multirow[b]{3}{*}{ Substrate } & \multicolumn{4}{|c|}{ Plasma source } \\
\hline & \multicolumn{2}{|c|}{ Hepatic vein } & \multicolumn{2}{|c|}{ Inferior vena cava } \\
\hline & $\begin{array}{c}\text { Plasma } \\
\text { alone }\end{array}$ & $\begin{array}{c}\text { Plasma } \\
\text { plus } \\
1.0 \mathrm{M} \\
\mathrm{NaCl}\end{array}$ & $\begin{array}{c}\text { Plasma } \\
\text { alone }\end{array}$ & $\begin{array}{c}\text { Plasma } \\
\text { plus } \\
1.0 \mathrm{M} \\
\mathrm{NaCl}\end{array}$ \\
\hline Chylomicrons & 1.62 & 0.44 & 0.80 & 0.16 \\
\hline $\begin{array}{l}\text { Low density } \\
\text { lipoproteins }\end{array}$ & 1.89 & 0.41 & 0.85 & 0.14 \\
\hline
\end{tabular}

it can be seen that the release of PHLA in the hepatectomized animals is slower, and that the maximal mean arterial PHLA level reached is significantly lower than in the intact animals. Similarly, if the hepatectomized dog injected with heparin into the femoral artery is compared with the peripherally injected intact dogs, significantly less PHLA was released after hepatectomy. This lower activity was shown not to be due to the appearance of inhibitors in plasma of hepatectomized dogs.

Our results are in accord with and extend the observations of other investigators regarding tissue sources of PHLA. Simultaneous injection of heparin and a nondiffusible dye into a limb artery results in rapid release of PHLA. Lipolytic activity and dye appear together in the venous blood from the limb (25) although the peak of lipolytic activity may lag slightly behind the peak dye concentration (26). Such experiments have been interpreted as evidence that PHLA was released from vascular endothelium or a tissue site close to endothelium. Since the liver contains a relatively large amount of vascular endothelium, we expected that it might well release PHLA, and this expectation was realized by our experimental observations. Release of PHLA from

TABLE $\mathbf{X}$

PHLA (mean microequivalents FFA per hour per milliliter plasma) after systemic injection of heparin in man

\begin{tabular}{|c|c|c|c|c|c|c|c|c|}
\hline Patient & Vessel sampled & Base line & $15 \mathrm{sec}$ & $2 \min$ & $4 \mathrm{~min}$ & $5 \mathrm{~min}$ & $7 \mathrm{~min}$ & $10 \mathrm{~min}$ \\
\hline A.B. & $\begin{array}{l}\text { Iliac artery } \\
\text { Hepatic vein }\end{array}$ & $\begin{array}{l}0.26 \\
0.26\end{array}$ & $\begin{array}{l}0.32 \\
1.93\end{array}$ & $\begin{array}{l}2.09 \\
3.77\end{array}$ & $\begin{array}{l}1.68 \\
3.84\end{array}$ & & $\begin{array}{l}3.56 \\
3.28\end{array}$ & $\begin{array}{l}3.36 \\
4.39\end{array}$ \\
\hline R.B. & $\begin{array}{l}\text { Iliac artery } \\
\text { Hepatic vein }\end{array}$ & $\begin{array}{l}0.20 \\
0.19\end{array}$ & $\begin{array}{l}0.18 \\
2.31\end{array}$ & $\begin{array}{l}1.32 \\
4.23\end{array}$ & & $\begin{array}{l}1.89 \\
4.63\end{array}$ & $\begin{array}{l}4.12 \\
4.01\end{array}$ & \\
\hline
\end{tabular}


the liver was very rapid and quite consistent with the findings in a perfused limb.

Our findings are not inconsistent with the observations in animals of several workers $(13,14)$ who have failed to demonstrate PHLA release from a perfused liver. In those older studies, blood samples were not obtained within the first few minutes after heparin injection. Therefore the rapid release of PHLA was not observed.

During the latter portions of the experiments on dogs with intact livers, the removal of PHLA from the circulation by the liver is apparent. There is a significant net decrease in PHLA when arterial and portal vein levels are compared with hepatic vein levels during the period from 20 to 45 minutes after heparin injection. Our observations are in accord with the findings, in both animals $(13-15)$ and in man $(17,21)$, of investigators who have collected blood samples 10 minutes or later after heparin injection and have demonstrated hepatic removal of PHLA. Available evidence indicates that the low activity observed in hepatic vein blood 10 minutes after heparin injection is not due to the presence of inhibitor substances $(21,25)$.

One of the patients (A.B.) had portal hypertension with an extensive portasystemic collateral circulation. It is probable that much of the portal blood flow in this patient was shunted around the liver via collaterals. The other patient (R.B.) had had an end to side portacaval shunt. The blood supply to the liver after this operation is entirely arterial. The possibility of PHLA release from other portions of the splanchnic circulation affecting the PHLA level in hepatic vein is thus obviated. Both of the patients exhibited an increase in hepatic vein PHLA in response to injection of heparin into the systemic circulation. Hepatic vein PHLA increased relatively rapidly after heparin injection and remained above the arterial PHLA level throughout the early portion of the experiment, implying that the enzyme was being released from the liver. The pattern of response in man was similar to that in the animals.

The peak levels of PHLA seen in both patients were approximately one-tenth those found in normal controls (21). This difference is probably a reflection of a decrease in the functional capacity of the cirrhotic liver to release PHLA. The fundamental nature of the decreased capacity to release PHLA remains obscure.

The lipolytic activity liberated from the liver and hind limbs showed characteristics similar to those of the clearing factor lipase of Robinson and French (2), and the lipoprotein lipase of Korn (4), in ability to hydrolyze chylomicrons and lipoproteins and clear glyceride emulsion, and in its sensitivity to inhibition by $1.0 \mathrm{M} \mathrm{NaCl}$. Inasmuch as lipoprotein lipase is thought to be responsible for the hydrolysis of chylomicron triglyceride that occurs during uptake of this lipid by adipose tissue and heart, the demonstration of hepatic release of lipolytic activity having the characteristics of lipoprotein lipase suggests that the liver may also have the capacity for extracellular lipolysis before uptake of chylomicrons. Currently the liver is thought to take up triglyceride without prior hydrolysis (27). Our findings raise the question as to whether another mechanism, possibly involving prior lipolysis, may be involved in the hepatic uptake of glyceride.

\section{Summary}

1) Postheparin plasma lipolytic activity was measured simultaneously in hepatic vein, abdominal aorta, portal vein, and inferior vena cava in 11 intact and five hepatectomized dogs after injection of heparin into the portal vein or a systemic artery.

2) In the animals, significant postheparin lipolytic activity was released from liver after portal vein and systemic arterial injection of heparin in intact dogs. This response was significantly impaired after hepatectomy.

3) The lipolytic activity liberated from the liver showed characteristics similar to those of lipoprotein lipase.

4) Studies of postheparin plasma lipolytic activity were also conducted in two cirrhotic patients undergoing hepatic vein catheterization. Postheparin plasma lipolytic activity was also apparently released from the liver in these patients in response to heparin injection into the systemic circulation.

5) Whether lipolytic activity liberated from the liver plays some physiological role in hepatic uptake of glycerides remains to be determined. 


\section{Acknowledgments}

We are indebted to Professor Sheila Sherlock for her guidance and support, to Dr. Anthony M. Dawson, who reviewed the manuscript, and to Misses Diane O'Grady and Rose Clarke, who provided valuable technical assistance.

\section{References}

1. Hahn, P. F. Abolishment of alimentary lipemia following injection of heparin. Science 1943, 98, 19.

2. Robinson, D. S., and J. E. French. Heparin, the clearing factor lipase, and fat transport. Pharmacol. Rev. 1960, 12, 241.

3. Anfinsen, C. B., E. Boyle, and R. K. Brown. The role of heparin in lipoprotein metabolism. Science 1952, 115, 583.

4. Korn, E.-D. Clearing factor, a heparin-activated lipoprotein lipase. I. Isolation and characterization of the enzyme from normal rat heart. J. biol. Chem. 1955, 215, 1.

5. Fredrickson, D. S., K. Ono, and L. L. Davis. Lipolytic activity of postheparin plasma in hyperglyceridemia. J. Lipid Res. 1963, 4, 24.

6. Korn, E. D., and T. W. Quigley, Jr. Lipoprotein lipase of chicken adipose tissue. J. biol. Chem. 1957, 226, 833.

7. McBride, O. W., and E. D. Korn. The lipoprotein lipase of mammary gland and the correlation of its activity to lactation. J. Lipid Res. 1963, 4, 17.

8. Robinson, D. S. Changes in the lipolytic activity of the guinea pig mammary gland at parturition. J. Lipid Res. 1963, 4, 21.

9. Barclay, M., E. Garfinkel, O. Terebus-Kekish, E. B. Shah, M. deGuia, R. K. Barclay, and V. P. Skipski. Properties of lipoprotein lipase extracted from liver of normal rats and livers and tumors of rats bearing Walker carcinosarcoma 256. Arch. Biochem. 1962, 98, 397.

10. Weld, C. B. Alimentary lipemia and heparin (abstract). Canad. med. Ass. J. 1944, 51, 578.

11. Swank, R. L., and S. W. Levy. Chylomicron dissolution. Dosage and site of action of heparin. Amer. J. Physiol. 1952, 171, 208.

12. Jeffries, G. H. The site at which plasma clearing activity is produced and destroyed in the rat. Quart. J: exp. Physiol. 1954, 39, 261.

13. Morris, B., and J. E. French. The uptake and metabolism of $\mathrm{C}^{14}$ labelled chylomicron fat by the isolated perfused liver of rat. Quart. J. exp. Physiol. 1958, 43, 180.

14. Spitzer, J. A., and J. J. Spitzer. Effect of liver on lipolysis by normal and postheparin sera in the rat. Amer. J. Physiol. 1956, 185, 18.

15. Boberg, J., L. A. Carlson, and L. Normell. Production of lipolytic activity by the isolated perfused dog liver in response to heparin. Biochem. J. 1964, 92, 43 P.

16. LeQuire, V. S., R. L. Hamilton, R. Adams, and J. M. Merrill. Lipase activity in blood from the hepatic and peripheral vascular beds following heparin. Proc. Soc. exp. Biol. (N. Y.) 1963, 114, 104.

17. Connor, W. E., and J. W. Eckstein. The removal of lipoprotein lipase from the blood by the normal and diseased liver. J. clin. Invest. 1959, 38, 1746.

18. Constantinides, P., Y. So, and F. R. C. Johnstone. Role of liver and kidney in development of heparin-induced lipemia clearing activity (LCA). Proc. Soc. exp. Biol. (N. Y.) 1959, 100, 262.

19. Yoshitoshi, Y., C. Naito, H. Okaniwa, M. Usui, T. Mogami, and T. Tomono. Kinetic studies on metabolism of lipoprotein lipase. J. clin. Invest. 1963, 42, 707.

20. Datta, D. V. Post-heparin plasma lipoprotein lipase levels in cirrhosis of the liver. Proc. Soc. exp. Biol. (N. Y.) 1963, 112, 1006.

21. Datta, D. V. Postheparin plasma 'lipoprotein lipase' activity in cirrhosis of the liver. Thesis, Ph.D. in Medicine, University of London, 1964.

22. Seldinger, S. I. Catheter replacement of the needle in percutaneous arteriography. A new technique. Acta Radiol. (Stockh.) 1953, 39, 368.

23. Korn, E. D. in Methods in Biochemical Analysis, D. Glick, Ed. New York, Interscience, 1959, p. 145.

24. Hill, A. B. Principles of Medical Statistics. London, The Lancet, 1961.

25. Robinson, D. S., and P. M. Harris. The production of lipolytic activity in the circulation of hind limb in response to heparin. Quart. J. exp. Physiol. $1959,44,80$.

26. Fraser, J. R. E., R. R. H. Lovell, and P. J. Nestel. The production of lipolytic activity in the human forearm in response to heparin. Clin. Sci. 1961, $20,351$.

27. Borgstrom, B., and P. Jordan. Metabolism of chylomicron glyceride as studied by $\mathrm{C}^{14}$ glycerol- $\mathrm{C}^{14}$ palmitic acid labelled chylomicron. Acta Soc. Med. upsalien. 1959, 64, 185. 